\title{
Aplikasi Pengontrol Robot Mobil Menggunakan Suara Berbasis Android
}

\author{
I Putu Aix Cendana, Anak Agung Ketut Agung Cahyawan Wiranatha, Kadek Suar Wibawa \\ Program Studi Teknologi Informasi Universitas Udayana \\ Bukit Jimbaran, Bali, Indonesia, telp. (0361) 701806 \\ e-mail: aixcendana4@gmail.com, agung.cahyawana@unud.ac.id, suar wibawa@yahoo.com
}

\begin{abstract}
Abstrak
Robot Mobil merupakan robot yang dibuat menggunakan peralatan penggerak berupa roda, sehingga dapat bergerak dan berpindah posisi. Robot mobil bergerak dan berpindah posisi secara otomatis sesuai program yang ditanamkan dan dapat juga dikontrol langsung secara jarak jauh. Smartphone merupakan salah satu alat yang dikembangkan untuk mengontrol robot secara jarak jauh. Aplikasi Pengontrol Robot Mobil Berbasis Android Menggunakan Suara merupakan aplikasi yang dirangcang untuk mengontrol pergerakan robot mobil menggunakan perintah suara berupa kata bahkan kalimat secara real-time. Aplikasi dibuat memanfaatkan Speech API Google untuk mengubah input-an suara menjadi teks sebelum dikirim ke robot mobil. Aplikasi dapat digunakan dengan cara terhubung ke Internet (online) untuk dapat menggunakan Speech API Google. Aplikasi juga dapat digunakan tanpa terhubung ke Internet (offline) dengan cara mengunduh offline speech recognition language terlebih dahulu. Respons pergerakan robot mobil setelah kata diucapkan pada aplikasi rata-rata 7 detik pada saat online dan 5 detik pada offline secara real-time.
\end{abstract}

Kata kunci: Robot Mobil,Smartphone,Suara,Speech API Google

\begin{abstract}
Robot Mobil is a robot that is made using wheel drive equipment, so it can move and move position. Automobile robots can move and move positions automatically not only according to embedded programs, but can also be controlled directly remotely. Android-Based Robot Car-Based Controller App is a built-in app for controlling the movement of car robots using voice commands. Applications are made using Google's Speech API to convert voice-totext inputs before being sent to a car robot. Applications can be used by connecting to the Internet (online) to be able to use Google's Speech API. The app can also be used without being connected to the Internet (offline) by downloading offline speech recognition language first. Response to the movement of the car robot after the spoken word on the application an average of 7 seconds online and 5 seconds offline in real-time.
\end{abstract}

Keywords : Lightning Robot Car,Smartphone, Sound, Speech API Google

\section{Pendahuluan}

Smartphone merupakan salah satu teknologi yang sedang berkembang di seluruh dunia saat ini [1]. Aplikasi yang terdapat di dalam smartphone dapat diaplikasikan pada bidang robotika, salah satunya adalah pengontrolan robot jarak jauh yang dikendalikan menggunakan smartphone [2]. Robot dapat dikontrol secara jarak jauh dengan dengan memanfaatkan telekomunikasi nirkabel. Komunikasi nirkabel dapat menghubungkan dua atau beberapa perangkat elektronik untuk bertukar data tanpa media kabel maupun terhubung dengan penghantar listrik [3].

Penelitian terkait pengontrolan robot sudah pernah dilakukan sebelumnya oleh Widiyanto \& Nuryanto yang berjudul "Rancang Bangun Mobil Remote Control Android dengan Arduino" [4], membahas mengenai perancangan aplikasi smartphone yang terhubung dengan mikrokontroler Arduino dengan memanfaatkan komunikasi Bluetooth. Aplikasi dibuat sebagai pengendali alat elektronik, dimana objek yang dikendalikan pada penelitian ini adalah mobil remote control mainan (RC Car). Penelitian yang dilakukan oleh Chauhan dan Chaudhari yang berjudul "Robotic Control using Speech Recognition and Android" [5], membahas mengenai teknologi untuk mengendalikan robot menggunakan suara. Aplikasi yang berjalan pada

Aplikasi Pengontrol Robot Mobil Menggunakan Suara Berbasis Android

(I Putu Aix Cendana) 
smartphone Android ini menggunakan metode pengenalan suara Mel Frequency Cepstral Koefisien (MFCC).

Penelitian pengontrolan robot dengan aplikasi smartphone menggunakan suara telah berhasil dibuat dengan menggunakan metode pengenalan suara Mel Frequency Cepstral Koefisien (MFCC). Pengenalan suara dengan Metode MFCC yang telah ada hanya menggunakan satu huruf dikarenakan semakin panjang pengucapan perintah, maka semakin sulit didalam pengenalan suaranya. Aplikasi Pengontrol Robot Mobil Berbasis Android Menggunakan Suara merupakan pengembangan dari penerapan metode Mel Frequency Cepstral Koefisien (MFCC), dimana pengontrolan dilakukan dengan pengenalan perintah kata bahkan kalimat. Aplikasi Pengontrol Robot Mobil Berbasis Android Menggunakan Suara dikembangkan menggunakan Android Studio. Aplikasi dirancang tidak hanya dapat dikontrol dengan perintah suara, tapi juga dapat dikontrol dengan perintah tombol dan pengetikan teks. Robot Mobil yang dikontrol melalui smarphone juga dirancang dapat berhenti secara otomatis, jika terdapat suatu halangan di depan robot mobil dengan memanfaatkan sensor ultrasonik (sensor jarak) yang terpasang pada bagian depan robot mobil.

\section{Metodologi Penelitian}

Metodologi penelitian Aplikasi Pengontrol Robot Mobil Menggunakan Suara Berbasis Android terdiri dari 4 tahapan yaitu melakukan studi literatur dengan mencari teori-teori penunjang pembuatan aplikasi melalui (buku, jurnal, artikel dan laporan penelitian), perancangan desain layout dan interface (antarmuka) aplikasi, implementasi sistem antara desain ke dalam kode program dan uji coba dilakukan untuk mengetahui seberapa jauh aplikasi yang dibangun dapat menyelesaikan masalah :

\subsection{Gambaran Umum Aplikasi}

Aplikasi Pengontrol Robot Mobil Berbasis Android Menggunakan Suara merupakan aplikasi yang dibuat untuk dapat mengontrol pergerakan robot mobil secara dinamis dan realtime dengan input-an suara. Aplikasi menggunakan media komunikasi nirkabel di dalam mengontrol pergerakan robot mobil. Secara umum komunikasi antara aplikasi pada smartphone dengan robot mobil dilakukan menggunakan media komunikasi bluetooth. Aplikasi dibuat dengan menggunakan bantuan Google Speech API sehingga membutuhkan jaringan Internet untuk dapat digunakan. Aplikasi juga dapat digunakan secara offline (tanpa terhubung dengan Internet) dengan syarat telah mengunduh offline speech recognition languege.

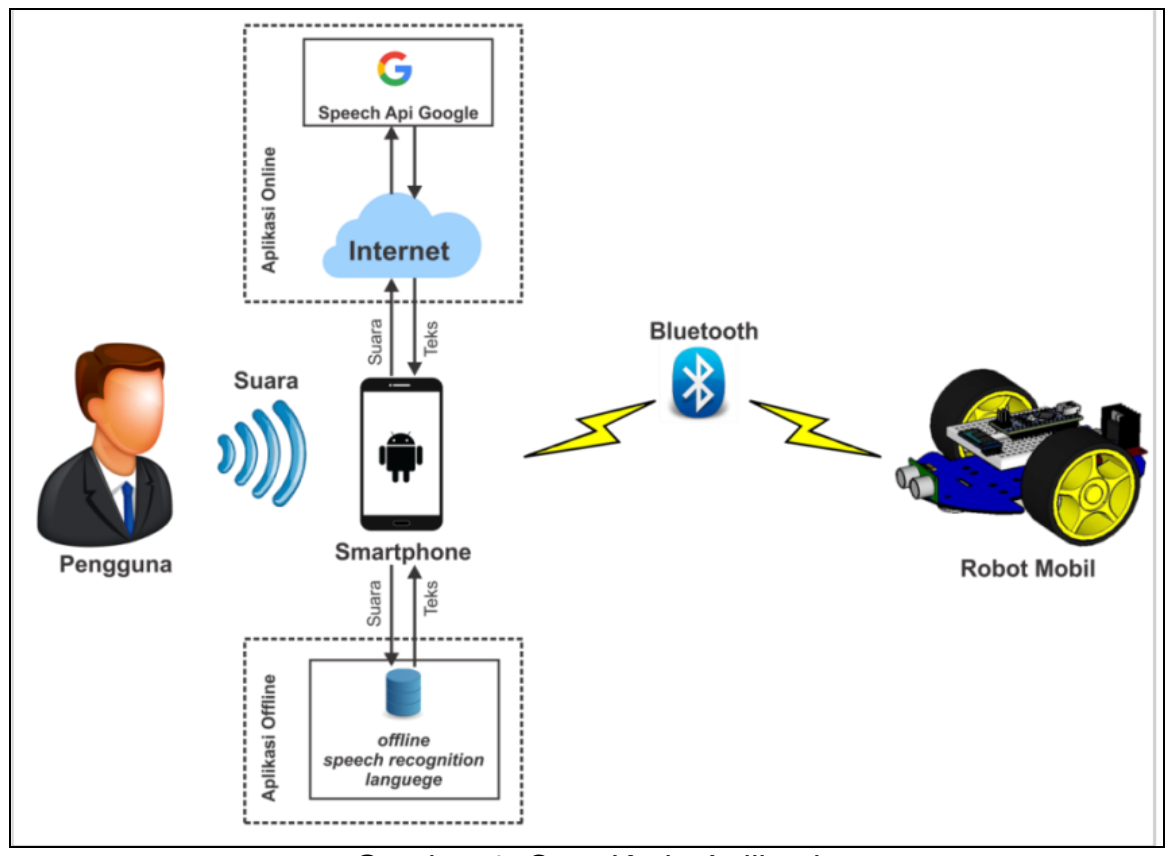

Gambar 1. Cara Kerja Aplikasi 
Gambar 1 merupakan gambaran umum cara kerja aplikasi Pengontrol Robot Mobil Menggunakan Suara Berbasis Android. Pengguna dapat mengendalikan robot mobil menggunakan aplikasi pengontrol robot pada smartphone setelah keduanya terhubung. Pairing bluetooth dilakukan terlebih dahulu antara smartphone dengan robot mobil hingga berhasil terhubung, sebelum pengguna dapat mengontrol robot mobil dengan aplikasi. Pengguna tinggal mengucapkan kata maju pada aplikasi smartphone untuk menggerakan robot mobil maju. Kata direkam pada smartphone untuk diubah menjadi teks dengan memanfaatkan bantuan Google Speech API, setelah teks didapat kemudian dikirimkan ke robot mobil. Teks yang dikirim oleh aplikasi pada smartphone diterima oleh robot mobil dan diproses oleh mikrokontroler sehingga robot mobil dapat bergerak sesuai dengan program yang telah diatur.

\section{Kajian Pustaka}

\subsection{Robot}

Robot merupakan sebuah alat mekanik yang dapat bekerja secara terus-menerus untuk membantu pekerjaan manusia seperti melakukan tugas fisik, yang dalam menjalankan tugasnya dapat dikontrol langsung oleh manusia ataupun bekerja secara otomatis sesuai program yang telah ditanamkan pada chip pengendali robot [6]. Robot dibuat memiliki tugas dan fungsi yang berbeda sesuai dengan kegunaannya seperti robot berkaki, robot beroda, robot terbang dan robot bawah air.

\subsection{Jaringan nirkabel}

Jaringan nirkabel dibedakan menjadi tiga jenis jaringan yaitu Wireless Wide Area Network (WWAN), Wireless Local Area Network (WLAN) dan Wireless Personal Area Network (WPAN). Wireless Personal Area Network (WPAN) merupakan teknologi jaringan nirkabel yang hanya dapat menjangkau area yang dekat. Bluetooth dan infrared merupakan contoh dari Wireless Personal Area Network (WPAN). Bluetooth merupakan teknologi yang memungkinkan dua perangkat saling terhubung tanpa menggunakan kabel dan saluran yang tidak terlihat [6]. Bluetooth dapat digunakan sebagai perangkat pengirim dan penerima data.

\subsection{Google Speech API}

Application Programming Interface (API) merupakan sebuah teknologi yang sedang dikembangkan oleh Google [7]. Application Programming Interface (API) memfasilitasi pertukaran informasi atau data antara dua atau lebih aplikasi perangkat lunak [8]. Google Speech API adalah sebuah framework yang dikembangkan oleh Google untuk pengenalan suara dan mengubahnya menjadi teks [9]. Input suara di-record pada perangkat smartphone kemudian dikirimkan ke server Google. Server Google memiliki tugas melakukan pengenalan dan mengubahnya menjadi teks menggunakan Algoritma Hidden Markov Model (HMM). Hasil konversi suara menjadi teks pada server Google akan dikirimkan kembali ke perangkat Android [10].

\section{Hasil dan Pembahasan}

Hasil dan pembahasan terdiri dari realisasi aplikasi pada smartphone, realisasi robot mobil dan pembahasan pengujian aplikasi terhadap pergerakan robot mobil.

\subsection{Hasil Perancangan Aplikasi}

Aplikasi Pengontrol Robot Mobil Menggunakan Suara Berbasis Android dibangun menggunakan bahasa pemrograman Java. 


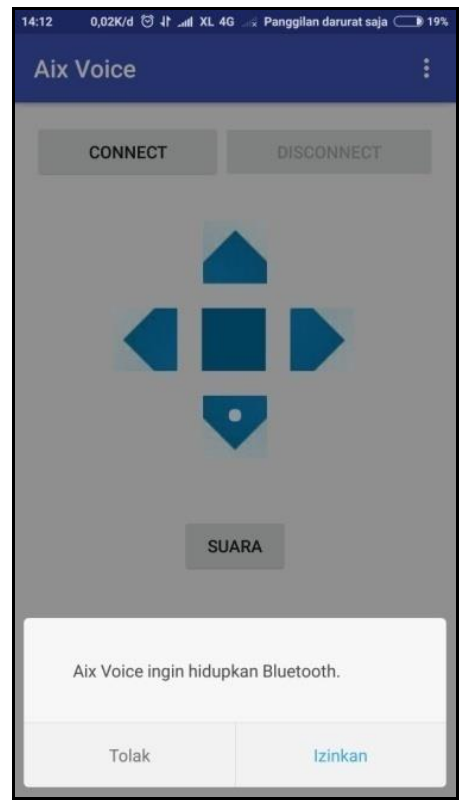

Gambar 2. Tampilan Awal Aplikasi

Gambar 2 merupakan tampilan awal ketika aplikasi dijalankan. Aplikasi dijalankan pertama kalinya meminta pengguna atau user untuk mengaktifkan bluetooth agar dapat menggunakan aplikasi. Aplikasi tertutup jika pengguna menolak untuk mengaktifkan bluetooth dan jika pengguna mengizinkan maka ada notifikasi bahwa bluetooth aktif.

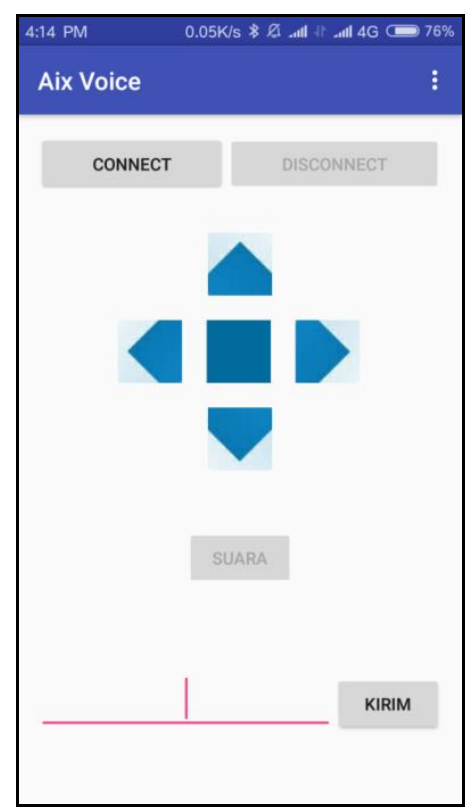

Gambar 3. Tampilan Utama Aplikasi

Gambar 3 merupakan tampilan utama dari aplikasi, dimana pada tampilan utama terdapat beberapa tombol yaitu Tombol Connect, Tombol Disconnect, Tombol Navigasi Arah, Tombol Suara dan Tombol Kirim. Tombol Connect merupakan tombol yang digunakan untuk melihat daftar perangkat bluetooth yang sudah di-pairing sebelumnya. Tombol Disconnect merupakan tombol yang digunakan untuk memutuskan sambungan bluetooth. Tombol Navigasi Arah dapat digunakan untuk mengontrol pergerakan robot mobil secara manual dan Tombol Suara digunakan untuk melakukan input perintah suara dalam mengontrol pergerakan robot mobil. Tombol Kirim digunakan untuk mengirim perintah dari hasil pengetikan teks ke robot mobil.

Aplikasi Pengontrol Robot Mobil Menggunakan Suara Berbasis Android 


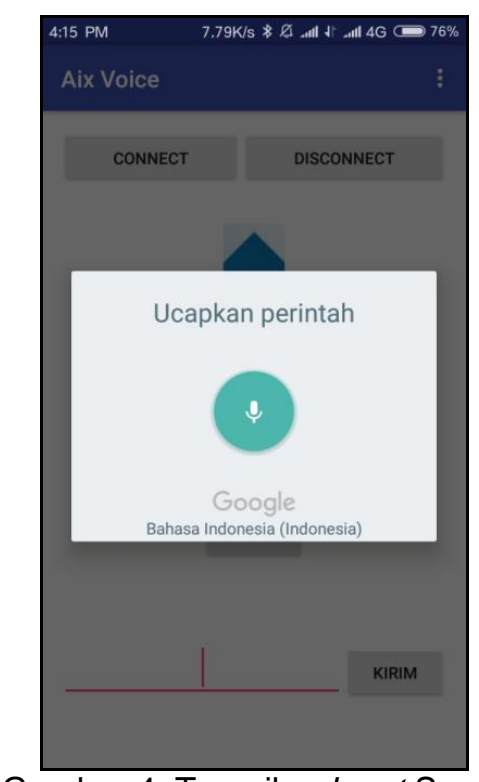

Gambar 4. Tampilan Input Suara

Gambar 4 merupakan tampilan aplikasi dalam mengontrol pergerakan robot mobil dengan input perintah suara. Aplikasi dibuat dengan memanfaatkan Google Speech API didalam mengubah input perintah suara pengguna menjadi teks sebelum dikirimkan ke robot mobil, maka aplikasi membutuhkan sambungan ke Internet untuk dapat bekerja. Pengucapan perintah suara yang diterima kemudian diubah menjadi teks oleh Google Voice. Teks yang didapat ditampilkan pada edit text sebelum dikirim ke robot mobil.

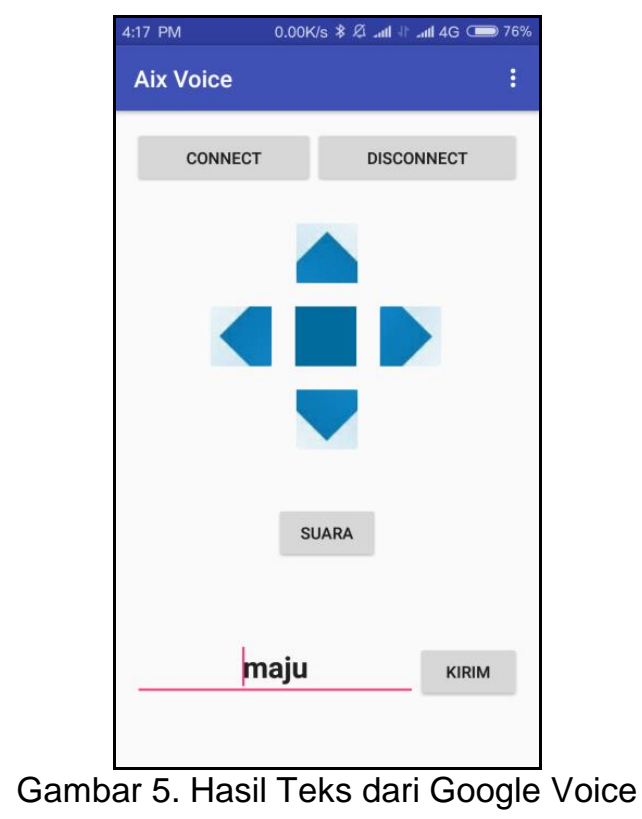

Gambar 5 merupakan hasil teks yang didapat dari Google Voice setelah pengucapan kata maju. Teks yang didapat dari hasil Google Voice tidak selalu sesuai dengan pengucapan saat melakukan record suara. Hasil teks yang didapat tidak sesuai dengan pengucapan maka dilakukan validasi dahulu sebelum teks dikirimkan ke robot mobil. Validasi teks dilakukan dengan membandingkan teks yang didapat dari Google Voice dengan hasil teks yang telah disimpan pada database yang telah dibuat berdasarkan kesamaan teks yang didapatkan pada pengujian sebelumnya. 


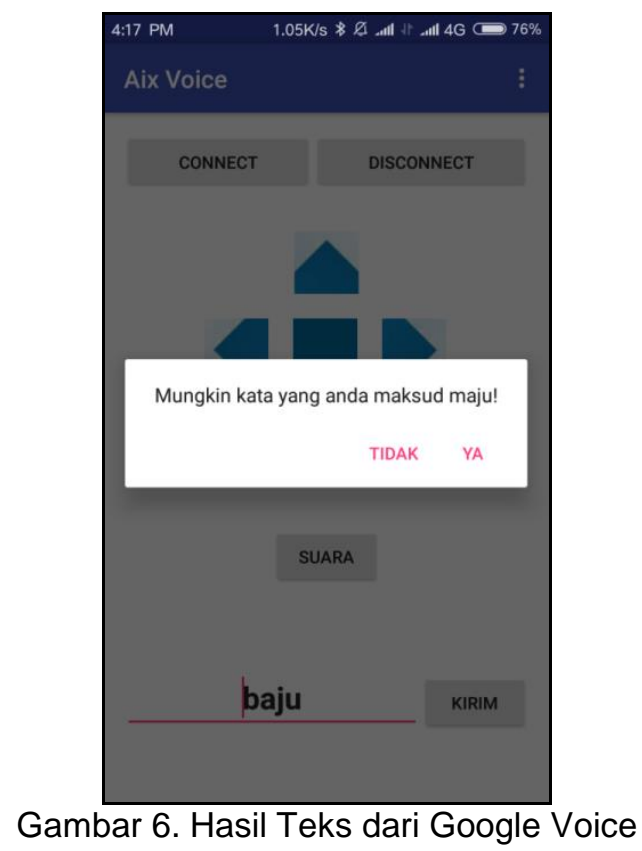

Gambar 6 merupakan validasi kata yang didapat dari hasil Google Voice. Teks baju didapatkan saat pengucapan kata maju, sehingga muncul validasi teks "Mungkin kata yang anda maksud maju!".

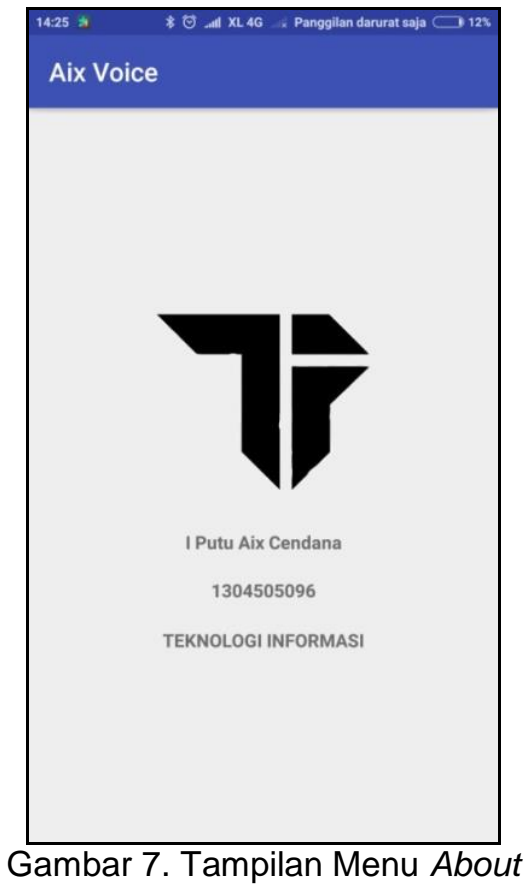

Gambar 7 merupakan tampilan menu about yang berisikan logo, nama, nim dan jurusan dari pembuat aplikasi.

\subsection{Hasil Perancangan Robot Mobil}

Robot mobil yang dibuat menggunakan Mikrokontroler Arduino Nano sebagai otak pemrosesannya. Robot mobil memiliki tinggi $7.5 \mathrm{~cm}$, panjang $13 \mathrm{~cm}$, lebar $10 \mathrm{~cm}$ dan berat 320 gram.

Aplikasi Pengontrol Robot Mobil Menggunakan Suara Berbasis Android 


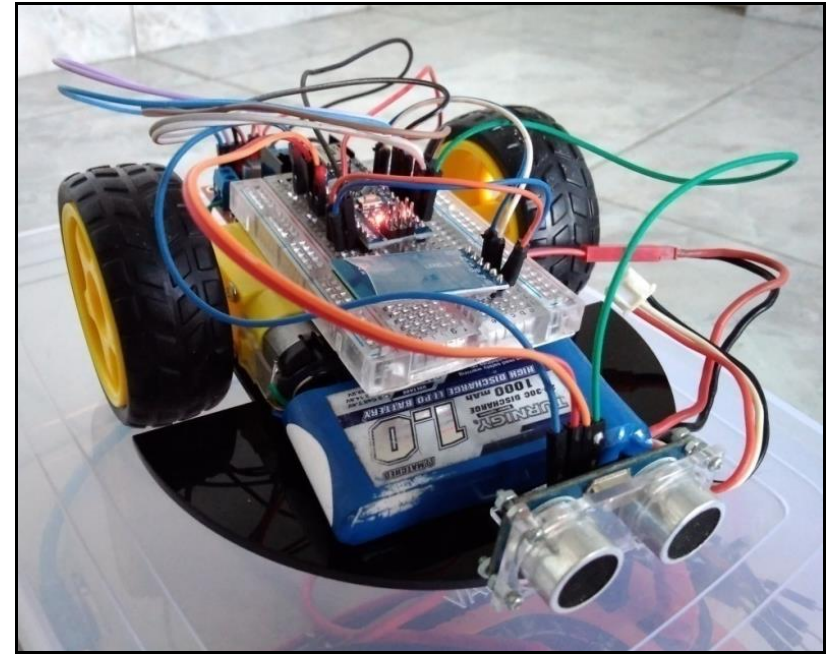

Gambar 8. Tampilan Robot Mobil

\subsection{Hasil Perancangan Aplikasi}

Analisa pengujian dilakukan untuk mengetahui bahwa aplikasi dan robot mobil yang telah dibuat dapat memenuhi harapan dan memberikan hasil keluaran sesuai dengan tujuan penelitian. Pengujian dilakukan pada aplikasi dan gerak robot mobil, begitu juga saat pengontrolan robot mobil dengan aplikasi.

a. Pengujian Pengiriman Perintah ke Robot Mobil

Pengujian pengiriman perintah ke robot mobil dilakukan untuk mengetahui data yang dikirim dari smartphone sudah benar diterima oleh robot mobil. Pengujian dilakukan dengan mengirimkan beberapa perintah seperti maju, mundur, kanan, kiri dan berhenti.

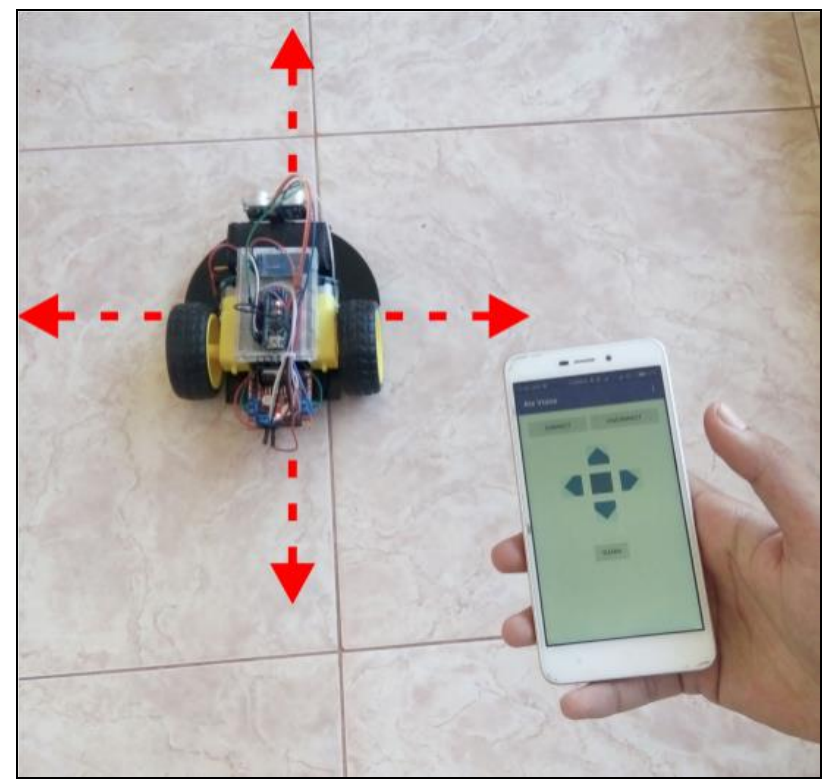

Gambar 9. Pengujian Pengiriman Perintah ke Robot Mobil

Gambar 9 merupakan pengujian pengiriman perintah maju dari smartphone ke robot mobil. Perintah yang dikirim dari smartphone selanjutnya dieksekusi oleh robot mobil. Hasil pengujian telah dirangkum pada Tabel 1. 
Tabel 1. Pengujian Pengiriman Perintah ke Robot Mobil

\begin{tabular}{lllcc}
\hline $\begin{array}{c}\text { Perintah pada } \\
\text { Smartphone }\end{array}$ & $\begin{array}{c}\text { Perintah yang } \\
\text { diterima Robot } \\
\text { Mobil }\end{array}$ & Hasil Uji & $\begin{array}{c}\text { Waktu pada } \\
\text { Aplikasi Online } \\
\text { (detik) }\end{array}$ & $\begin{array}{c}\text { Waktu pada } \\
\text { Aplikasi Offline } \\
\text { (detik) }\end{array}$ \\
\hline Maju & Maju & Berhasil & 7 & 5 \\
Mundur & Mundur & Berhasil & 8 & 5 \\
Kanan & Kanan & Berhasil & 8 & 5 \\
Kiri & Kiri & Berhasil & 7 & 4 \\
Berhenti & Berhenti & Berhasil & 8 & 5 \\
\hline
\end{tabular}

Tabel 1 merupakan hasil pengujian pengiriman perintah ke robot mobil, dimana dilakukan beberapa pengujian perintah seperti maju, mundur, kanan, kiri dan berhenti. Hasil pengujian menunjukkan semua perintah yang dikirim dari smartphone telah berhasil diterima dengan benar oleh robot mobil. Respons pergerakan robot mobil setelah kata diucapkan pada aplikasi rata-rata 7 detik pada aplikasi online dan rata-rata 5 detik pada aplikasi offline.

b. Pengujian Aplikasi Aix Voice dalam Pengontrolan Robot Mobil

Pengujian aplikasi dalam pengontrolan robot mobil dilakukan dengan menggunakan simulasi lintasan dalam bentuk persegi yang berukuran $100 \mathrm{~cm} \times 100 \mathrm{~cm}$, dengan permukaan datar dan alasnya berwarna putih atau terang, serta terdapat alas kotak hitam kecil pada satu sisi lintasannya yang berfungsi sebagai penanda tempat finish dan start. Gambar 10 merupakan simulasi pengujian di dalam lintasan.

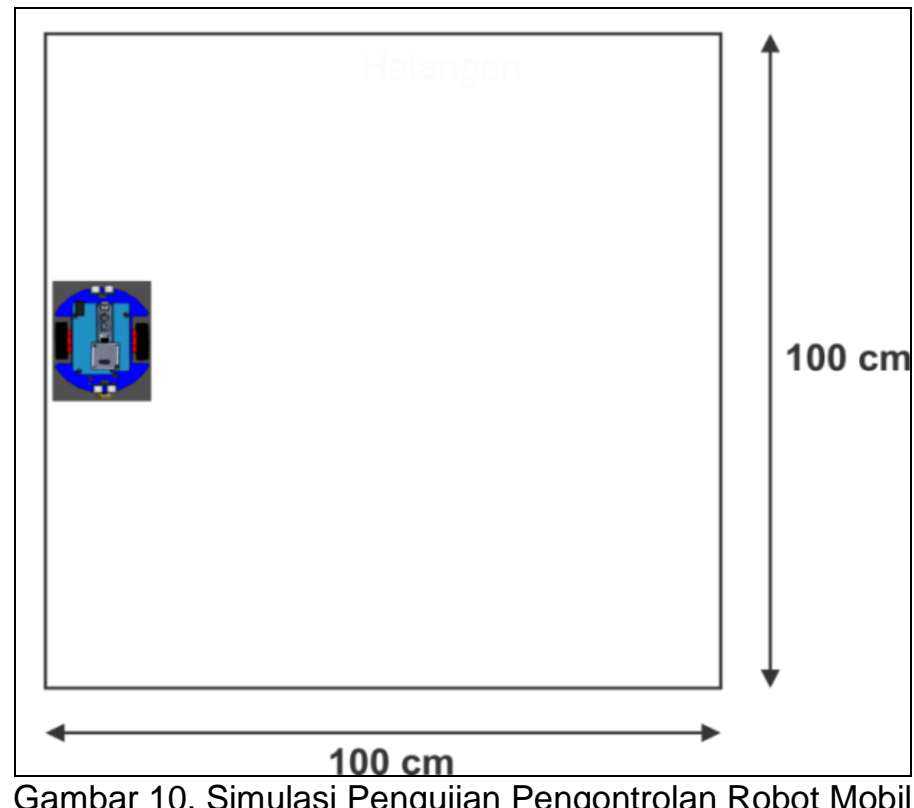

Pengujian pada lintasan dilakukan sebanyak 5 kali percobaan. Gambar 11 merupakan pengujian robot mobil di lintasan oleh pengguna. 


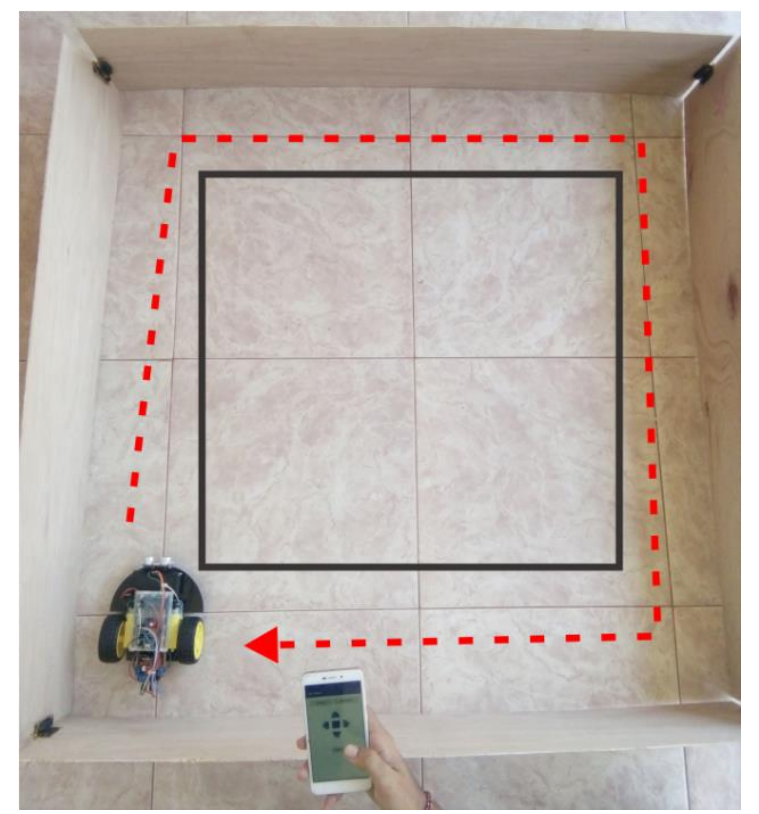

Gambar 11. Pengujian Pengontrolan Robot Mobil

Gambar 11 merupakan pengujian robot mobil pada lintasan. Percobaan pertama dilakukan dengan menggunakan aplikasi secara online. Percobaan dilakukan sebanyak 5 kali perulangan sehingga didapatkan waktu tempuh yang berbeda-beda dari posisi start sampai dengan finish. Hasil pengujian robot mobil pada lintasan dirangkum pada Tabel 2.

Tabel 2. Hasil Waktu Percobaan Robot Mobil dengan Aplikasi Online

\begin{tabular}{cc}
\hline Percobaan & Waktu Tempuh \\
\hline Percobaan Pertama & 1 menit 30 detik \\
Percobaan Kedua & 1 menit 44 detik \\
Percobaan Ketiga & 1 menit 46 detik \\
Percobaan Keempat & 1 menit 38 detik \\
Percobaan Kelima & 1 menit 50 detik \\
\hline
\end{tabular}

Pengujian kedua dilakukan dengan menggunakan aplikasi secara offline. Hasil pengujian robot mobil pada percobaan kedua dirangkum pada Tabel 3.

Tabel 3. Hasil Waktu Percobaan Robot Mobil dengan Aplikasi Offline

\begin{tabular}{cc}
\hline Percobaan & Waktu Tempuh \\
\hline Percobaan Pertama & 1 menit 2 detik \\
Percobaan Kedua & 55 detik \\
Percobaan Ketiga & 1 menit 10 detik \\
Percobaan Keempat & 1 menit 12 detik \\
Percobaan Kelima & 1 menit 18 detik \\
\hline
\end{tabular}

\section{Kesimpulan}

Aplikasi pengontrol pergerakan robot mobil secara real-time dan dinamis menggunakan perintah suara telah berhasil dikembangkan dengan memanfaatkan Speech API Google. Aplikasi dapat mengontrol pergerakan robot mobil secara real-time dimana perintah kata dilakukan secara berkesinambungan terus menerus. Aplikasi juga bersifat dinamis tidak hanya dapat dikontrol dengan perintah suara, tapi dapat dikontrol dengan perintah tombol dan pengetikan teks. Aplikasi dapat mengontrol pergerakan robot dengan input-an suara berupa perintah kata bahkan kalimat. Rata-rata pengiriman perintah suara hingga dieksekusi oleh robot mobil membutuhkan waktu 8 detik pada aplikasi online dan 5 detik pada aplikasi offline. Aplikasi dapat mengontrol pergerakan robot mobil pada lintasan yang telah dibuat dengan waktu tempuh rata-rata 1 menit 41 detik dengan waktu tercepat 1 menit 30 detik pada keadaan 
aplikasi online dan waktu tempuh rata-rata 1 menit 7 detik dengan waktu tempuh tercepatnya 55 detik pada aplikasi offline.

\section{Daftar Pustaka}

[1] M. G. Arsawiguna, A. A. K. Agung, C. Wiranatha, and K. S. Wibawa, "Rancang Bangun Aplikasi Game Tajen Berbasis Android menggunakan Artificial Intelligence", Lontar Komputer, vol. 6, no. 2, pp. 84-95, 2015.

[2] Pande, M. Ngurah, and Linawati, "Sistem Kendali Otomatis Prototype Robot Mobil untuk Parkir Pintar Menggunakan Komunikasi Nirkabel”, Teknol. Elektro, vol. 15, p. 2, 2016.

[3] K. S. Wibawa, A. A. K. O. Sudana, and P. W. Buana, "Mikrokontroler Sistem Komunikasi Sensor Jamak Menggunakan Serial Rs-485 Multi Processor Communication", Lontar Komputer, vol. 7, no. 2, pp. 798-807, 2016.

[4] A. Widiyanto and Nuryanto, "Rancang Bangun Mobil Remote Control Android dengan Arduino," Creative Information Technology Journal, vol. 3, no. 1, pp. 2354-5771, 2015.

[5] G. Chauhan and P. Chaudhari, "Robotic Control using Speech Recognition and Android", International Journal of Engineering Research and General Science, vol. 3, no. 1, pp. 1210-1216, 2015.

[6] A. Kadir, Zero to a Pro: Arduino. Andi, yogyakarta, 2015.

[7] I. N. Piarsa, P. P. W. Buana, and A. Mahasadhu, "Android Navigation Application with Location- Based Augmented Reality", International Journal of Computer Science, vol. 13, no. 4, pp. 1694-0814, 2016.

[8] I. N. Piarsa, A. A. K. O. Sudana, and G. W. M. Gunadi, "Web-based GIS by using Spatial Decision Support System (SDSS) Concept for Searching Commercial MarketplaceUsing Google MAP API", International Journal of Computer Applications, vol. 50, no. 7, pp. 7780-0867, 2012.

[9] Supriyanta, P. Widodo, and M. Susanto, "Aplikasi Konversi Suara ke Teks Berbasis Android Menggunakan Google Speech Api”, Bianglala Informatika, vol. 2, no. 2, pp. 1119, 2014.

[10] Reddy and E. Mahender, "Speech To Text Conversion Using Android Paltform", Internaitonal Journal of Engineering Research and Applicaiton (IJERA), vol. 1, no. 2, pp. 253-258, 2013 